\title{
REVIEWS
}

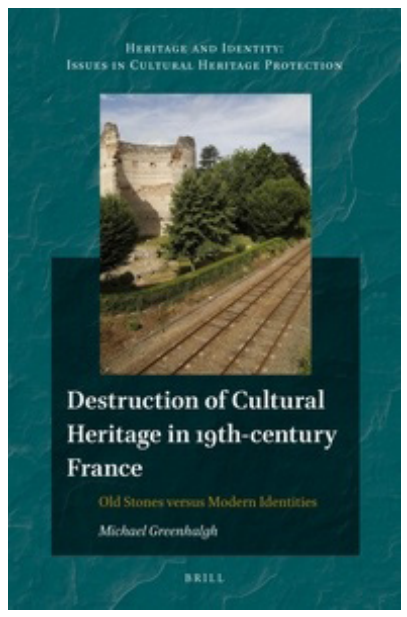

Nathan SCHLANGER

\section{Destruction of Cultural Heritage in 19th-century France: Old Stones versus Modern Identities}

[by Michael Greenhalgh]

Destruction of Cultural

Heritage in 19th-century

France

Brill

ISBN: 9789004289208

462 pages

Construction and destruction go hand in hand, as we are reminded by Architecture and Conservation Historian, Michael Greenhalgh, in his substantial and thoroughly documented study, but it does not necessarily follow that they are synchronous or calibrated. The development of modern France throughout the 19th-century is a case in point, when urban expansion, infrastructure building and industrialisation also entailed so much demolition and clearances of ancient monuments, fortifications and archaeological sites. Large swaths of the population, Greenhalgh insists, seemed quite happy with these transformations and the subsequent losses. This was obviously the case with the builders and developers who initiated these works. Moreover, national and municipal administrations alongside many local residents seemed content, striving as they did to reach beyond the narrow confines and insalubrious conditions of their provincial towns, and thereby benefited as much as possible from the new comforts of sanitation, drainage, water supplies, means of transport, and modern urban standards. Others, however, admittedly far fewer in numbers including scholars, historians, antiquarians and archaeologists, found causes to complain about 
this process, especially insofar as it wantonly and unnecessarily destroyed vast tracks of ancient and medieval landscapes. Just after the French Revolution, the term "vandalism" was coined precisely to convey this notion of deliberate or negligent collateral damage done by demolition or decay, often on economically motivated grounds, that completely ignored the historical or symbolic values of the monuments affected and ruthlessly erased.

The bulk of Greenhalgh's book represents an encyclopedic inventory, partly thematic and partly geographical, documenting the destruction of standing monuments and archaeological sites across France. Alongside discussions of the ambiguous impact of the military preserving some fortifications and destroying many others, Greenhalgh dedicates two interesting chapters to the topics of technology and modernization along with their architectural consequences. The mechanisms of infrastructure development in the 19th century are here examined from the perspective of their impact on historical monuments and archaeological sites, including railways, roads, canals, as well as factories and other new types of buildings required by the accelerating industrialisation. The digging and clearing upheaval associated with the railway, for example, was quite unprecedented in its scale and intensity. The impact reached both the laying down of level tracks across the countryside, with various cuts and tunnels truncating hills and backfilling valleys, along with the clearing of access tracks and roads to train stations situated near historic town centres.

The subsequent five chapters take a gazetteer-like geographical or regional approach, showing how destruction - particularly of Roman and Gallo-roman Antiquities on which Greenhalgh focuses - has occurred throughout the country on a massive scale and not just in Provence and the Mediterranean south. Whether in Avignon or in Amiens, or indeed in the emblematic case of Paris, whose medieval streets were swept aside and reshaped by the all-powerful prefect Haussmann during the second Empire, some archaeologists were nonetheless present, alert and on site. Greenhalgh shows this through two chapters, bearing one on vandalism and ignorance, and the following to the organisation of scholarship and museums. On the latter, the verdict is rather severe: the best repositories of movable finds that were rescued from impacted monuments 
served (in the author's view) as alibis to cover up for this massive destruction. Archaeologists themselves did not fare much better. Up to a point, they had to consort and coordinate with the enemy, the "vandal" developers, who were bringing finds to light in order to clear them. In Greenhalgh's concise formulation, the quintessential idea was "knock it down, but write it up and put the debris in a museum, and of course photograph what went" (p. 211).

We thus approach the paradox of modernisation, which destroys the material past, but also brings it to light and makes it (to a lesser or greater extent, to be fought for) available for study. This brings us to the thrust of Greenhalgh's argument, at times hidden beneath the factual compendia: as he sets to "explain and document those processes which left France monumentally - physically and spiritually - short changed on both her heritage and her identity", Greenhalgh wonders, "Could it be that the widespread optimistic assessment of France's conservation achievements is overblown?" (p. 8-9). Could it be that the presentation of 19th century France as being particularly concerned with the past only reflects the "triumphalism and concomitant amnesia" of current scholarship ( $p$. $x i)$, indeed "a creation myth for the universal sweetness and light that flooded French archaeology" (p. 148)? In a sense, Greenhalgh is quite right to maintain that the processes involved were more fragile, slow, and faltering than is usually claimed (ibid). By providing an "uplifting interpretation", the current narrative of saving and preservation overlooks the losses which have occurred, and which are exhaustively (and at times exhaustingly) documented in this book. It can be granted that official administrative memory tends to be self-laudatory, but it would have been useful had Greenhalgh enriched his argument with a balanced historiographical survey or assessment of tendencies in the study of French modernisation, or in the history of heritage management as a whole. As we have little or none of that, we are left to wonder by what criteria is this sense of achievement allegedly overblown and unwarranted? Is it by comparing the "real" number or proportion of the monuments destroyed versus those preserved upon the modernisation onslaught? Rather, it can be proposed that the accomplishment is not numerical as much as it is conceptual relating to an emergent sensitivity and recognition of the need for compensatory or mitigating measures further anchored in legal, administrative and 
138 - Nathan SCHLANGER - Review: Destruction of Cultural Heritage in...

intellectual frameworks. I argue that what remains to be explored is the processes by which sites and monuments, following the French Revolution, gradually lost their values and then how an attachment to these materials vestiges of the past emerged and developed as a factor of belonging and identity. The question left outstanding, in other words, brings us back to the title of this rich and useful book (despite having a range of formal and editorial shortcomings): when and how did the debris swept aside by modernisation cease to be mere old stones, good at best for recycling, and become instead this new and increasingly compelling category of "cultural heritage", henceforth to be preserved and cherished? 